\title{
Ampulla of Vater Cancer pT4 TNM Finding v7
}

National Cancer Institute

\section{Source}

National Cancer Institute. Ampulla of Vater Cancer pT 4 TNM Finding V7. NCI Thesaurus. Code C90273.

Ampulla of Vater cancer with tumor invading peripancreatic soft tissues or other adjacent organs or structures other than pancreas. (from AJCC 7th Ed.) 